\title{
Rafał NAKONIECZNY
}

(Katowice)

\section{KOŚCIÓŁ WOBEC INNOWIERCÓW W DE SYNODIS HILAREGO Z POITIERS Aspekt terminologiczny}

Życie i działalność Hilarego przypadły na sam środek kontrowersji ariańskiej. Gdy pomysły Ariusza poczęły poruszać umysły teologów, był jeszcze dzieckiem, ostatecznej klęski arianizmu już jednak nie dożył.

Na przełomie lat 357 i 358 przebywający na wygnaniu we Frygii Hilary dowiedział się o sprzeciwie niektórych biskupów galijskich wobec przyjętej wcześniej przez biskupów Galii deklaracji z Sirmium z 357 roku. Biskupi ci napisali Hilaremu, iż zerwali łączność z Saturninem i że pragną poznać opinie dotyczące synodów Wschodu, symboli wiary oraz jego własne zdanie ${ }^{1}$. Wzbudziło to radość Hilarego, który postanowił przerwać dwuletnie milczenie ${ }^{2}$. Pod koniec 358 lub na początku 359 r. dokonał redakcji pisma De synodis, któremu nadał formę listu.

Zainteresowanie autora De synodis ogranicza się w sposób wyraźny do współczesnej mu sytuacji Kościoła, a i tę ujmował on jedynie pod pewnym kątem. Wiele z problemów chrześcijaństwa instytucjonalnego poznał Hilary dopiero na wygnaniu. Kontakt ze Wschodem z całą jego religijną teorią (tj. postanowieniami synodów) i praktyką (przez co rozumiem tutaj subiektywnie ocenianą przez niego jakość wiary) otworzył mu oczy na wielopłaszczyznowość

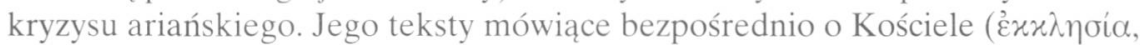
ecclesia) podzielić można na dwie grupy: pierwszą stanowią cytowane dokumenty Soboru Nicejskiego i następujących po nim synodów, drugą natomiast kilka wypowiedzi samego Hilarego.

${ }^{1}$ Hilary kilkakrotnie wspomina w swym dziele, iż jest ono odpowiedzią na wyraźną prośbę Galów, por. De synodis 66, PL 10, 524: „ostendi vobis, sicut voluistis, quae ante expositae fides essent ab Orientalibus episcopis"; zob. tamże 2, 5 i 8; por. M. Meslin, Hilaire et la crise arienne, w: Hilaire et son temps. Actes du colloque à l'occasion du XVI ${ }^{\mathrm{e}}$ centenaire de la mort de saint Hilaire (Poitiers, 29 IX - 3 X 1968), Paris 1969, 27; M.J. Le Guillou, Hilaire entre l'Orient et l'Occident, w: Hilaire de Poitiers, évêque et docteur. Cinq conférences données à Poitiers à l'occasion du XVI ${ }^{\mathrm{e}}$ centenaire de sa mort, Paris 1968, 44.

${ }^{2}$ Por. Hilarius, De synodis 1-5. 
Przypadki występowania terminu ecclesia w zacytowanych przez Hilarego tekstach soborowych i synodalnych ukażę w porządku chronologicznym. Zbiór ważnych dla naszego autora dokumentów rozpoczyna Sobór Nicejski (325), którego postanowień stał się niezłomnym obrońcą. W zakończeniu nicejskiego wyznania wiary ( przez naszego Biskupa czytamy:

„Eos autem, qui dicunt, «Erat quando non erat, et ante quam nasceretur non erat, et quod de non exstantibus factus est, vel alia substantia aut essentia, dicentes convertibilem et demutabilem, Deum», hos anathematizat catholica Ecclesia" ${ }^{3}$.

Termin „ecclesia” pojawia się tu w kontekście potępienia i usunięcia z Kościoła (anathema) błędnowierców. Dwadzieścia dwa lata później synod w Sardyce (347), nawiązując częściowo w kwestiach teologicznych do powyższej problematyki, wypowiedział się, według Hilarego, w sposób następujący:

„Eos autem, qui dicunt de non exstantibus esse filium Dei, vel ex alia substantia, et non ex Deo, et quod erat aliquando tempus aut saeculum quando non erat, alienos novit sancta et catholica Ecclesia. Similiter et eos, qui dicunt tres esse deos; vel Christum non esse Deum et ante saecula, neque Christum, neque filium eum esse Dei; vel cum ipsum esse Patrem et Filium et sanctum Spiritum, vel innascibilem filium; vel quod neque consilio neque voluntate Pater genuerit Filium: anathematizat sancta et catholica Ecclesia"4.

Kolejnym tekstem zawierającym słowa wykluczania ze wspólnoty kościelnej jest skierowane przeciw Fotynowi postanowienie synodu w Sirmium (351):

„Eos autem qui dicunt: «De nullis exstantibus Filius, vel de altera substantia, et non ex Deo; et quod erat tempus vel saeculum quando non erat», alienos scit sancta et catholica Ecclesia"

Ten pierwszy anatematyzm z Sirmium zacytuje jeszcze Hilary w całości nieco dalej, gdy będzie potępiał błędy Fotyna ${ }^{6}$. Nieco inną budowę ma dziewiąty anatematyzm z Ancyry (358) w jego przekazie:

„Et si quis, propterea quod numquam Pater Filius intelligitur, et quod Filius numquam Pater intelligitur, alium dicens Filium praeter Patrem, propterea quod alius sit Pater, alius sit Filius, secundum quod dictum est: «Alius est qui testimonium perhibet mihi, qui me misit Pater» (J 5, 32), propter hanc piam in Ecclesia intelligendam proprietatem personae Patris et Filii, timens ne quando idem intelligatur Filius et Pater, similem non dicat etiam iuxta essentiam Patri: anathema sit"

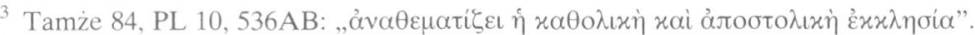

4 Tamże 34, PL 10, 507BC.

5 Tamze 38, PL 10, 510A.

${ }^{6}$ Por. tamze 39, PL 10, 513A.

7 Tamże 22, PL 10, 497C.
} 
Nietrudno zauważyć z powyższego zestawienia tekstów, iż dominuje w nich aspekt negatywny. Określając jak najdokładniej, jaką naukę należy uznać za błędną, Kościół samookreślający się jako „sancta Ecclesia” lub „sancta et catholica Ecclesia", ustami swych biskupów decyduje się, często z góry, wykluczyć głosicieli herezji ze swej społeczności.

1. Wykluczenie z Kościoła. W tekstach powyższych obserwujemy cztery alternatywne sposoby wyrażenia decyzji usunięcia kogoś z Kościoła, trzy $\mathrm{z}$ nich to zdania $\mathrm{z}$ ecclesia jako podmiotem: „(ecclesia) anathematizat”, „(ecclesia) alienos novit”, „(ecclesia) alienos scit”. Czwarta forma, zdecydowanie najczęstsza ${ }^{8}$ w De synodis, to odnoszone tym razem do osoby głoszącej błędne nauki wyrażenie - anathema sit.

W pozostałych ustępach analizowanego przez nas dzieła, gdzie w zdaniach dotyczących wykluczenia z Kościoła nie występuje rzeczownik ecclesia, sytuacja jest analogiczna. Sporadyczne formy z alienus ustępują zdecydowanie zwrotom $\mathrm{z}$ rzeczownikiem anathema lub pochodnym od niego czasownikiem anathematizare $^{9}$. Gdy chodzi o formy rzeczownikowe, obok podstawowego zwrotu anathema (sit), obserwujemy kilka innych. Odnotować tu należy najpierw zdanie oznajmujące z hilariańskiego komentarza do decyzji synodu w Ancyrze:

„, anathema ergo est, qui in Patre et Filio naturae similitudinem ad abolendam Filii personalem significantem praedicabit" 10 .

Powyższe stwierdzenie jest po prostu logiczno-gramatycznym wariantem bezprzyimkowej konstrukcji anathema (esse), podobnie jak zdanie:

„atque ob id anathema sunt, qui Patrem asserant dissimilis sibi naturae patrem esse"11.

Z kolei przy komentowaniu dokumentów z Ancyry Hilary pisał:

„,cum enim in anathemate sit, qui solitarium atque unicum in accipientis et dantis professione crediderit" ${ }^{, 12}$;

podobnie w zbijaniu błędów Fotyna:

„,cum enim in anathemate sit, qui ex Maria Dei filium hominem sine Deo dixerit"13;

${ }^{8}$ Głównie z racji przywoływania przez Hilarego wielu anatematyzmów synodalnych, por. np. De synodis 12-30, 38-40 et passim.

9 Czasownika tego brak również w innych pismach Hilarego, por. R.J Kinnavey, The Vocabulary of St. Hilary of Poitiers as contained in Commentarius in Matthaeum, Liber I Ad Constantium and De Trinitate. A Morphological and Semasiological Study, Washington 1935, 63.

${ }^{10}$ De synodis 22, PL 10, 497B.

11 Tamże 20, PL 10, 496C.

12 Tamże 14, PL 10, 491A

13 Tamże 47, PL 10, 515B. 
oraz:

„,cum enim in anathemate sit Christum Deum denegans”"14.

Taką samą konstrukcję obserwujemy w końcowej adhortacji Hilarego:

„Date veniam, Fratres, dolori meo: impium est, quod audetis. Non patior hanc vocem, ut in anathemate sit homousion secundum religiosam intelligentiam confitens. Nomen nihil habet criminis, quod sensum non perturbat religionis" ${ }^{15}$.

Kolejnym przypadkiem użycia konstrukcji in anathemate (esse) jest teologiczna refleksja, którą dzieląc się Autor nie ma wątpliwości, że myślenie odmienne jest całkowicie błędne, a konsekwencja akceptacji takich poglądów jest wiadoma:

„Ne quod nuncupatae essentiae in Patre et Filio, per indissimilem naturam, nomen unum est, occasionem haereticis praestaret, ut innascibilem Deum, vel patrem eius, nasci de Maria praedicarent; occursum est salutaris definitione sententiae, ut anathema esset hoc confidens" 16 .

Rzeczownik anathema bez czasownika obserwujemy w wypowiedzi następującej:

„Ordinati enim ab his sumus, et eorum sumus successores. Renuntiemus episcopatui, quia officium eius ab anathemate sumpserimus" ${ }^{\prime 17}$.

Anathema w tekście powyższym oznacza ojców Soboru Nicejskiego, których potępienie pociąga za sobą jako logiczną konsekwencję zakwestionowanie godności biskupiej potępiających, gdyż są następcami (successores) tych pierwszych.

Innym przypadkiem użycia terminu anathema bez czasownika, tym razem w funkcji określającej inny rzeczownik, ukazuje nam kolejny tekst hilariańskiego komentarza:

„Adiectio nunc Paracleti, anathemati obnoxiam facit innascibilis in eo Dei praedicationem"18.

Ideę wykluczenia z Kościoła wyraża również Hilary, choć stosunkowo rzadko, czasownikiem , anathematizare”. Poza ukazanymi wyżej przypadkami użycia formuły „(ecclesia) anathematizat”, czytamy w cytowanym przez Hilarego wyznaniu wiary synodu antiocheńskiego (341):

„Hanc ergo habentes fidem, et ab initio et usque in finem habituri in conspectu Dei et Christi, omnem haereticam et pravam sectam anathematizamus" ${ }^{\prime 19}$.

14 Tamże 51, PL 10, 518A.

15 Tamże 91, PL 10, 544A.

16 Tamże 42, PL 10, 513-514.

17 Tamże 91, PL 10, 544A.

18 Tamże 53, PL 10, 519A.

19 Tamże 30, PL 10, 503B. 
Podobnie w hilariańskiej adhortacji pod koniec traktatu:

„Oro vos, Fratres, adimite suspicionem, excludite occasionem. Ut probari possit homoeusion, non improbemus homousion. Cogitemus tot sacerdotes sanctos et quiescentes: quid de nobis Dominus iudicabit, si nunc anathematizantur a nobis?"20.

Szczególną uwagę warto zwrócić na fragment dotyczący negatywnej reakcji niektórych biskupów na sukcesy arian w Sirmium:

„Ut cum hanc prorumpentem a Sirmio haeresim et vos condemnassetis, et illi cum anathemate iudicassent, sciretis tamen in cuius fidei professione id ipsum, quod vos gesseratis, etiam ab Orientalibus episcopis esset effectum; et vos, quos maxime vellem futuris synodis probabiles elucere, non praeter uno atque eodem apostolicae fidei sensu catholica sentientes, aliqua saltem a catholicae fidei sinceritate, ignorata verborum opinione, differre ${ }^{" 21}$.

Z jednej strony mamy tu koniunkcję anathema i czasownika iudicare, z drugiej zaś tekst ten ukazuje nam bezpośrednio, obok wyrażającego ideę wykluczenia ze wspólnoty Kościoła terminu anathema, bliski znaczeniowo czasownik condemnare, zawierający w sobie negatywny ładunek, dotyczący potępienia nie tylko jako stanu emocjonalnego, ale i konkretnego działania. W tym drugim ujęciu łączność condemnare z anathema (anathematizare) jest bardzo wyraźna. Następstwo - tak logiczne, jak i chronologiczne - potępienia i wykluczenia ukazuje bardzo dobrze następujący tekst Hilarego:

„Nam etiam haec in superiori fide constituta damnatio est: ut anathema esset, qui Patrem dissimilis sibi essentiae diceret patrem"22.

Zaznaczyć trzeba w tym miejscu, iz Hilary, podobnie jak inni autorzy tego okresu, nie zna jeszcze łacińskich terminów excommunicatio czy excommunica$r e^{23}$, które później będą powszechnie używane w języku kościelnym, zwłaszcza w prawie kanonicznym. Używa natomiast, choć sporadycznie, rzeczownika communio, który oznacza tę utracalną więź z innymi współwyznawcami, jakiej pozbawić może decyzja biskupów zebranych podczas synodu, jak miało to miejsce np. w przypadku Saturnina z Arles: „Saturninus [...] negata ipsi usque hoc tempus toto iam triennio communione" 24 . Wspólnota prawowiernych chrześcijan określona jest przez Hilarego mianem „,communio dominica”25;

20 Tamże 91, PL 10, 543A.

21 Tamże 8, PL 10, 485C-486A.

22 Tamże 74, PL 10, 529A.

23 Brak tych terminów w słowniku Hilarego potwierdza cytowana już terminologiczna praca Kinnaveya.

24 De synodis 2, PL 10, 481A.

25 Por. tamże 4 i 8, PL 10, 483B i 485A. 
raz określa życzliwych dla siebie biskupów zwrotem „communionem se meam continentes” ${ }^{26}$. Czasownika „continere” używa także w zdaniu „communio dominica continetur" 27 .

2. Potępienie. W powyższych fragmentach, ukazujących użycie terminu anathema i czasownika pochodnego anathematizare, pojawiła się już dwukrotnie idea potępienia. Hilary wyraża ją w swym traktacie zazwyczaj za pomocą wyrazów zbudowanych $\mathrm{z}$ tematu damn-: damnatio, damnare i condemnare. Przeanalizujmy teraz teksty zawierające terminy z tematem -damn-pod kątem częstotliwości użycia różnych jego wariantów oraz badając jego koniunkcje z innymi wyrazami. Rzeczownik damnatio, który użyty został w cytowanym wyżej zdaniu: „Nam etiam haec in superiori fide constituta damnatio est"28, jako podmiot występuje jeszcze w innym miejscu:

„Concludi damnatio eius haeresis, propter quam conventum erat, expositione totius fidei cui adversabatur, oportuit" ${ }^{\prime 29}$.

Poza tymi przypadkami użycia interesującego nas obecnie rzeczownika w mianowniku, Hilary posługuje się nim także inaczej, jak np. w zdaniu:

„Fraus ergo haec omnis in damnatione est: quae Deum Verbum, quod in principio apud Deum erat, tamquam verbum esse insitae ac prolatae vocis affirmet" ${ }^{30}$.

Konstrukcji „in damnatione (esse)” używa jeszcze w zdaniu: „cum enim in damnatione sit, Patrem et Filium duos deos dicere" 31 , natomiast podobnie (już bez esse) czytamy w zdaniu: „Atque ita non relinquitur vitiosae intelligentiae quaestio, ubi in vitii damnatione communis assensus est" ${ }^{32}$. Analizując tych kilka przypadków użycia rzeczownika damnatio zwrócmy uwagę na wyrazy, do których się on odnosi. Wprawdzie osoba działająca, to znaczy potępiająca, nie jest tu bliżej określona, ale poznać możemy obiekt tego potępienia. W trzech przypadkach Hilary wypowiada się na temat błędów doktrynalnych, które przedstawia w swym dziele i wytrwale wszelkimi możliwymi argumentami zwalcza. Używa przy tym rzeczowników: haeresis (damnatio haeresis), fraus (fraus in damnatione est) i vitium (in vitii damnatione). Z kolei inną sytuację widzimy w zdaniu „cum enim in damnatione sit, Patrem et Filium duos deos dicere", gdzie występuje koniunkcja z pełniącym funkcję podmiotu bezokolicznikiem dicere (dicere in damnatione sit).

\footnotetext{
${ }^{26}$ Por. tamże 8, PL 10, 485B.

27 Por. tamże 4, PL 10, 483B.

28 Tamże 74, PL 10, 529A.

29 Tamże 61, PL 10, 521C-522A.

30 Tamż 46, PL 10, 515A.

31 Tamże 41, PL 10, 513C.

32 Tamże 82, PL 10, 535A
} 
Obok rzeczownika damnatio napotykamy wielokrotnie pokrewny czasownik damnare. Omawiając piąty anatematyzm z Sirmium Hilary m.in. pisze: „Haeresis ergo creaturam esse Dei filium profiteri ausa, damnatur”33. Występująca tu koniunkcja z rzeczownikiem (haeresis damnatur) przypomina konstrukcje, jakie tworzy, jak stwierdziliśmy, termin damnatio (damnatio haeresis). Już na początku swego dzieła nasz autor zwraca się do biskupów Galii słowami:

„Gratulatus sum in Domino [...] vos [...] missam proxime vobis ex Sirmiensi oppido infidelis fidei impietatem, non modo non suscepisse, sed nuntiatam etiam significatamque damnasse" ${ }^{34}$.

W tym przypadku Hilary używa w kontekście błędu doktrynalnego rzeczownika impietas. Ten sam termin w koniunkcji z damnare obserwujemy w zdaniu:

„haec impietas damnatur, quae audeat intemporalem nativitatem ad unicam ac singularem innascibilis essentiae referre substantiam" ${ }^{35}$.

Tak więc do zaobserwowanych już w koniunkcji z damnatio rzeczowników fraus, vitium i występującego także z damnare - haeresis dopisać możemy jeszcze rzeczownik impietas. Zupełnie inaczej przedstawia się sytuacja w miejscu, w którym nasz autor zwraca się do wyimaginowanego adwersarza:

„Quid fidem meam in homousion damnas, quam per homoeusii professionem non putes non probare? Damnas enim fidem meam, vel potius tuam, cum damnas intelligentiam eius in nomine. Sed male alius intelligit? Damnemus in commune vitiosam intelligentiam, non auferamus fidei securitatem" ${ }^{136}$.

Terminy, które obserwowaliśmy wcześniej określając czyjś pogląd, posiadały już same w sobie negatywny wydźwięk. W opinii i ustach człowieka wypowiadającego swój sąd, samo zastosowanie któregokolwiek z tych rzeczowników było jednoznaczne. Chodziło tam o mniej lub bardziej zamierzone odstępstwo, fałszywą naukę. Natomiast w przypadku tego tekstu, mamy do czynienia z połączeniem czasownika damnare z terminami mającymi zazwyczaj znaczenie jak najbardziej pozytywne (w najgorszym razie można je uznać za neutralne) fides i intelligentia. Znaczenia negatywnego nabiera ten drugi termin dopiero po dodaniu do niego przymiotnika vitiosus (vitiosa intelligentia). Bardzo podobną sytuację mamy w zdaniu: „Ne damnemus patres, ne animemus haereticos: ne dum haeresim apellimus, haeresim nutriamus" ${ }^{37}$, gdzie przemyślane zestawienie czasownika damnare z pełnym szacunku patres (w omówionym

\footnotetext{
33 Tamże 18, PL 10, 494C.

34 Tamże 2, PL 10, 481A.

35 Tamże 26, PL 10, 500A

36 Tamże 88, PL 10, 540A.

37 Tamze 91, PL 10, 545.
} 
wyżej znaczeniu „,biskupi-poprzednicy; ojcowie soboru”) wywołuje efekt mocnego kontrastu, gdyż sam użyty termin pater nasuwa czytelnikowi skojarzenie z człowiekiem, któremu należy się szacunek, a nie potępienie.

Zobaczmy, jakie są jeszcze inne przedmioty rzeczywistego, bądź jedynie potencjalnego, potępienia w dziele Hilarego. W toku teologicznej argumentacji czytamy: „Deorum numerositate damnata, et Deo tantum uno praedicato, negari Deus filius Dei non potest ${ }^{\prime 38}$. Z treści wywodów Hilarego wynika, iż rozprawia się w tym miejscu z poglądami o istnieniu dwóch bądź nawet trzech bogów, w miejsce wyznawanego przez prawowiernych chrześcijan jednego Boga w trzech osobach. Warto zauważyć, iż wśród określeń dotyczących niewłaściwego pojmowania chrześcijańskich dogmatów, mamy tu do czynienia już nie $\mathrm{z}$ pojęciem szerokim, wymagającym sprecyzowania, jak np. haeresis, lecz z terminem wyjątkowo konkretnym numerositas Deorum. Zwróćmy jeszcze uwagę na ciekawe zdanie:

„Totum hoc itaque catholica fides damnat, in quo et demutabilis Pater dicitur, et natus Filius abnegatur" ${ }^{\prime 39}$.

Przede wszystkim, po serii bezosobowych sformułowań damnatio, damnatur oraz retorycznych damnas, (ne) damnemus obserwujemy tu użyty jako podmiot rzeczownik fides. Odnośnie do błędnej nauki powiada zatem Hilary, iż fides catholica damnat. Taka konstrukcja występuje tylko w tym miejscu De synodis $^{40}$. Po drugie, tutaj również czytelnik poinformowany jest wprost, na czym polega potępiony przez katolików pogląd (demutabilis Pater dicitur, natus Filius abnegatur). Tej precyzji nie wykazuje już kolejny termin, użyty w kontekście sporów teologicznych:

„Praetermissa itaque quaestionae novitatis, ne in his quidem residet quaestio, quae communi omnium nostrum iudicio damnatur" ${ }^{\prime 1}$.

Potrzeba za każdym razem wyjaśnić czytelnikowi, na czym dokładnie polega odrzucona czy potępiona quaestio. Podobnie rzecz się ma, gdy Hilary czyni aluzję do wydarzeń z nieodległej przeszłości, wydarzeń, które czytelnik powinien znać i kojarzyć. Tak np. wspominając niechlubny udział w synodzie w Sirmium Potamiusza i Hozjusza pisze:

„[Potamius atque Osius] ipsi sentientes confirmantesque, concesserant, ad professionem ignorantiae errorisque compellerent; ut ipsi rursum subscribendo damnarent quod fecerant. Quod utique ideo fecerunt, ut aliud ante damnarent" ${ }^{42}$.

\footnotetext{
38 Tamże 57, PL 10, 520A.

39 Tamże 45, PL 10, 515A.

${ }^{40}$ Koniunkcję tę spotykamy natomiast w De Trinitate VI 10: „pia Ecclesiae fides damnat”.

${ }^{41}$ De synodis $82, \mathrm{PL} 10,535 \mathrm{~A}$.

42 Tamże 3, PL 10, 483A.
} 
Ciekawa i zgrabna jest budowa tych zdań z parą czasowników damnare i facere: „damnarent quod fecerant [...] fecerunt, ut aliud ante damnarent”. Jeżeli jednak czytelnik poza zatrzymaniem się nad konstrukcją tej wypowiedzi ma zrozumieć intencję autora, musi cofnąć się do czasów Soboru Nicejskiego i działalności wspomnianych biskupów między tym soborem (325), a drugim synodem w Sirmium (357).

Obok rzeczownika damnatio i czasownika damnare Hilary użył również w omawianym obecnie kontekście przymiotnika w zdaniu pytającym:

„quanto magis trium deorum in Patre et Filio et Spiritu Sancto nuncupatio damnabilis est? Quod tamen quia haeretici dicunt, recte catholici condemnant"43.

Wypowiedź powyższa jest przykładem zupełnie wyjątkowego użycia w De synodis terminu damnabilis, a sens słów ,nuncupatio trium deorum damnabilis est” znamy już ze słów następnego rodziału pisma Hilarego: „Deorum numerositate damnata". Jednocześnie skłania nas ona do zajęcia się trzecim wariantem terminu o temacie damn-, a mianowicie condemnare. Ten czasownik złożony występuje zdecydowanie rzadziej od prostego damnare. Analiza fragmentów, w których Hilary posługuje się nim pozwoli nam na określenie jego sensu i pola znaczeniowego, także w stosunku do damnare. W słowach kierowanych do ,przebudzonych” z ariańskiego odrętwienia biskupów Galii czytamy:

„ea, quae inter nos atque Orientales episcopos mutuis suspicionibus detinentur, per me, qui in Orientis partibus continebar, exponenda vobis, licet iam scientibus, atque edenda existimavi: ut cum hanc prorumpentem a Sirmio haeresim et vos condemnassetis" 44 .

Podobnie, jak obserwowaliśmy wyżej, mamy tu zatem połączenie condemnare haeresim. W innym miejscu czytamy z kolei: „Par itaque in condemnandis impietatibus haereticorum nostra sententia est" ${ }^{25}$. Występowanie w tym kontekście rzeczownika impietas równiez jest nam znane. Natomiast inne określenia błędnej nauki zawierają zdania: ,itaque doctrinae huius perversitas condemnatur ${ }^{, 66}$ oraz „Condemnatur ergo impiae professionis temeritas [...] dissimilitudinem ausa sit praedicare naturae" ${ }^{47}$. Zatem do odnotowanych juz haeresis i impietas (haereticorum) dołączyć należy bardziej rozbudowane, choć właściwie nie wnoszące żadnej nowej treści poza emocjami, określenia „doctrinae perversitas” i ,impiae professionis temeritas”.

\footnotetext{
43 Tamże 56, PL 10, 519D-520A.

44 Tamże 8, PL 10, 485B.

45 Tamze 82, PL 10, 535A.

46 Tamże 43, PL 10, 514B.

47 Tamże 19, PL 10, 495.
} 
Jest również u Hilarego miejsce zawierające konstrukcję łączącą condemnare nie z poglądami, lecz z głoszącymi je ludźmi: „,condemnans eos, qui de non exstantibus esse Filium dicerent" 48 .

Zestawienie tekstów, w których wyrażona została idea potępienia, najczęściej idei, rzadziej człowieka, pozwala nam stwierdzić, iż nie ma zasadniczo żadnej różnicy pola znaczeniowego terminów o temacie -damn-. Użycie damnatio, damnare lub condemnare wydaje się być u Hilarego jedynie kwestią stylistyczną. Za wyborem któregoś z tych alternatywnych wyrazów nie kryje się nic głębszego, nic, co mogłoby wpłynąć na zmianę sensu wypowiedzi, a nawet na intensywność emocji zawartych w danym słowie. Najlepiej obrazuje to fragment, w którym nasz autor używa obok siebie wszystkich trzech alternatywnych określeń:

„Praetermissa itaque quaestionae novitatis, ne in his quidem residet quaestio, quae communi omnium nostrum iudicio damnatur [...]. Par itaque in condemnandis impietatibus haereticorum nostra sententia est [...]. Atque ita non relinquitur vitiosae intelligentiae quaestio, ubi in vitii damnatione communis assensus est ${ }^{49}$.

Wspomnę jedynie w tym miejscu, iż badając De synodis pod kątem synonimów terminu o temacie -damn- odnotowałem skromnie reprezentowany przez jeden fragment w tym kontekście czasownik improbare:

„Sed quia sicut inter caetera insaniarum genera, etiam hoc quoque proferri ab imipiis solet; idcirco a sanctis debuit improbari" ${ }^{50}$.

Istotne jest dla obiektywnej oceny osobowości naszego autora, iż zdecydowana większość tekstów, w których wyraża Hilary ideę potępienia, odnosi się do sformułowań, słów, sui generis heretyckich dogmatów, bardzo rzadko wprost do człowieka. Konstatacja ta, obok wielu istotnych elementów biografii Hilarego, w której nie brak spotkań, rozmów i modlitwy z innowiercami, pozwala stwierdzić, iż nasz autor był (używając współczesnego określenia) człowiekiem dialogu. Potrafił także, w miarę konsekwentnie, odróżnić pogląd od osoby, która go głosi. Na odróżnieniu verba et gesta od ich podmiotu zasadza się przecież chrześcijańska miłość. Warto także zauważyć, jaka jest różnica między tak chętnie szafowanym, kierowanym zwykle wprost do osób anathema, a przeanalizowanym właśnie terminem damnatio. Trudno się oprzeć wrażeniu, że Hilary znacznie ostrożniej niż o wykluczeniu z Kościoła pisał o potępieniu człowieka ${ }^{51}$.

48 Tamże 35, PL 10, 507C.

49 Tamże 82, PL 10, 535A.

50 Tamże 55, PL 10, 519C.

51 Stosunek Hilarego do heretyków opisuje M. Figura, Das Kirchenverständnis des Hilarius von Poitiers, Freiburg - Basel - Wien 1984, 270-284. 
W wypowiedziach pochodzących już od samego Hilarego spotykamy termin ecclesia znacznie częściej niż w cytowanych oficjalnych dokumentach będących owocem spotkań biskupów. Mówiąc o swojej roli w Kościele i znaczeniu samego pisma, które wysyła, autor De synodis przedstawia ją słowami:

„,conscius mihi, hoc me Ecclesiae militiae meae stipendium debere, ut per has litteras, episcopatus mei in Christo vocem, secundum doctrinas evangelicas, destinarem" 52 .

Wcześniejsze swoje milczenie, będące reakcją na długotrwały brak jakiejkolwiek odpowiedzi z Galii na poprzednie listy, tłumaczy Hilary podpierając się nakazem Ewangelii:

„mihi quoque apud vos tacendum arbitrabar, dominicae sententiae admodum memor, qua post primum atque iteratam conventionem, eos, qui etiam sub testimonio Ecclesiae inobedientes exsisterent, haberi sicut ethnicos publicanosque iussisset (Mt 18, 15) ${ }^{53}$.

Także sugestywny opis prześladowań ze strony innowierców zawiera interesujący nas obecnie termin:

„, his perturbationibus vexari Ecclesia coepta est, ut exsulent episcopi, demutentur sacerdotes, plebes terreantur, fides periclitetur, humano arbitrio ac potestate doctrinae dominicae decreta statuantur, 54 .

Obserwujemy tu ciekawą personifikację Kościoła, który doznaje ucisku (vexari). W tym miejscu rodzi się brzemienne w skutki pytanie: z czyich rąk? Kto jest prześladowcą? Kontekst dzieła i znajomość realiów życia chrześcijan czasów Hilarego każą nam zapomnieć o niechętnym, bądź nawet nieprzyjaznym, stosunku władcy do rozwijającej się na terenie jego imperium nowej religii. W chwili, gdy nasz autor pisze te słowa, cesarzem nie jest już przecież Dioklecjan, a chrześcijanin Konstancjusz. Jeśli więc popierana przez dwór propaganda proariańska, używająca mniej lub bardziej siłowych argumentów, nazwana jest przez Hilarego dręczeniem Kościoła, czyli de facto atakiem z zewnątrz, oznacza to, iż nie uważał on arian za członków kościelnej społeczności. Nie należą oni zatem do ecclesia. W De synodis nie wyraża wprawdzie tego poglądu bezpośrednio czytelnym zwrotem, że są oni extra Ecclesiam, ale w tym kontekście spotkać to można w innym dziele naszego autora ${ }^{55}$. Termin ecclesia w tym tekście oznacza więc jedynie ortodoksów, niezależnie, jak się zdaje, od stanu i miejsca w hierarchii (episcopi, sacerdotes, plebes).

\footnotetext{
52 De synodis 92, PL 10, 546A.

53 Tamże 1, PL 10, 480B.

54 Tamze 4, PL 10, 483B.

55 Por. De Trinitate VII 3.
} 
Przyjrzyjmy się teraz, w jaki sposób pisze Hilary o reakcji na poglądy uznane za herezję:

„De homousio vero, quod est unius essentiae, tractantes, primum idcirco respuendum pronuntiastis, quia per verbi huius enuntiationem substantia prior intelligeretur, quam duo inter se partiti essent. Intelligo vitium in intelligentia. Et profanus hic sensus est, et communi iudicio ab Ecclesia respuendus. Secundo quoque id addidistis, quod patres nostri, cum Paulus Samosatenus haereticus pronuntiatus est, etiam homousion repudiaverint: quia per hanc unius essentiae nuncupationem solitarium atque unicum sibi esse Patrem et Filium praedicabat. Et hoc sane nunc quoque profanissimum Ecclesia recognoscit, Patrem et Filium in his nominum professionibus ad unionis ac singularis solitudinem negata personarum proprietate revocare" 56 .

Podmiotem działania jest tu zatem Kościół, który może respuere czy recognoscere poszczególne sformułowania, zawarte w wyznaniach wiary, w tym przypadku mowa o charakterystycznym dla kontrowersji ariańskiej problemie z terminami ónoov́øı s i ómoเoúøıs. Zapytajmy i teraz, jakie znaczenie niesie z sobą u Hilarego rzeczownik ecclesia? W tekście analizowanym poprzednio oznaczał on ogół wiernych duchownych i świeckich. Tu jednakże mamy już do czynienia z prawem decydowania o słuszności bądź niesłuszności sformułowań w formułach wiary. Prawo takie przysługuje jednak jedynie biskupom zebranym na soborze czy synodzie. W porównaniu z szerokim obrazem Kościoła prześladowanego, zakres znaczeniowy rzeczownika ecclesia w tym miejscu znacznie się zawęził.

Inny aspekt omawianego zagadnienia podsuwa nam tekst, w którym - co bardzo rzadkie w tym dziele - autor wspomina cesarza w kontekście tarć ortoi heterodoksji:

„Homines enim perversi eo usque proruperant, ut cum hoc ipsi praedicare publice non auderent, Imperatorem tamen fallerent ad audiendum. Fefellerunt enim ignorantem regem, ut istiusmodi perfidiae fidem bellis occupatus exponeret, et credendi formam Ecclesiis nondum regeneratus imponeret. Contradicentes episcopos ad exsilium coegerunt" ${ }^{57}$.

Efektem działania wpływowych zauszników cesarza (homines perversi) stało się narzucenie (nowej) wiary Kościołom (ecclesiae). Po pewnym czasie dochodzi do sytuacji, którą obserwował przebywający na Wschodzie banita Hilary:

„Nam tantum Ecclesiarum Orientalium periculum est, ut rarum sit huius fidei (quae qualis sit, vos iudicate) aut sacerdotes aut populum inveniri. Male enim per quosdam impietati auctoritas data est: et exsiliis episcoporum, quorum causam non ignoratis, vires auctae sunt profanorum. Non peregrina loquor,

56 De synodis 81, PL 10, 534AB.

57 Tamże 78, PL 10, 531A. 
neque ignorata scribo: audivi ac vidi vitia praesentium, non laicorum, sed episcoporum" 58 .

Chwilowe (jak się później okazało) zwycięstwo arianizmu i wyraźna przewaga liczebna zwolenników oficjalnej wówczas wiary, zaznaczone zostały także w innym fragmencie:

„Nunc quia fides mea atque vestra, quantum mihi conscius sum, apud Deum non periclitatur; et ostendi vobis, sicut voluistis, quae ante expositae fides essent ab Orientalibus episcopis, sed paucis (repetam enim, quia secundum numerum Ecclesiarum Orientalium, episcoporum paucorum fides ista est); ipse quoque, quid de divinis rebus secundum doctrinam apostolicam sentirem, professus sum" ${ }^{19}$.

Trzy powyżej ukazane teksty, poza smutnym z perspektywy Nicejczyka obrazem sytuacji, łączy użycie terminu ecclesia w pluralis. Pozwala nam to na odnotowanie kolejnego znaczenia tego rzeczownika. Obok sensu „ogół wierzących” i „oficjalne spotkanie biskupów” ecclesia oznacza u naszego autora bliżej nieokreśloną mniejszą grupę wiernych, jak nietrudno się domyślić, na czele ze swym biskupem, czyli Kościół lokalny, coś pomiędzy dzisiejszą diecezją a parafią. Brak większej ilości tekstów w De synodis, zawierających ten termin, nie pozwala nam na dalsze zbadanie zakresu znaczeniowego ecclesia ${ }^{60} \mathrm{w}$ tym piśmie biskupa Poitiers.

\title{
DIE KIRCHE ANGESICHTS DER ANDERSGLÄUBIGEN IN DE SYNODIS DES HILARIUS VON POITIERS \\ Die terminologische Hinsicht
}

\author{
(Zusammenfassung)
}

In dem vorliegenden Artikel wird die Reaktion der Kirche auf die unorthodoxen Anschauungen in terminologischer Hinsicht besprochen. Sowohl in den offiziellen Kirchenurkunden als auch in den Äußerungen des Hilarius selbst wird der Gebrauch der Begriffe analysiert, die sich auf den Ausschluß aus der Kirche und die Verdammung beziehen (ecclesia anathemat, alienos novit; damnatio, damnare, condemnare).

58 Tamże 63, PL 10, 522C.

59 Tamże 66, PL 10, 524BC.

${ }^{60}$ Por. Kinnavey, The Vocabulary of St. Hilary of Poitiers, s. 124: „, (church) the whole body of believers; an ecclesiastical assembly; a council; a synod". 